\title{
Perancangan Adjustable Handlebar untuk Sepeda Motor dengan Dua Sistem Pengaturan
}

\author{
David Oboe Kristiawan ${ }^{{ }^{*}}$, Yopi Yusuf Tanoto $^{2 *}$, Ian Hardianto Siahaan ${ }^{3}$, Naldi $^{4}$ \\ 1,3,4 Program Studi Teknik Mesin, Fakultas Teknologi Industri, Universitas Kristen Petra \\ Jl. Siwalankerto 121-131, Surabaya 60236, Indonesia \\ 2 Pusat Studi Sustainable Energy, Universitas Kristen Petra \\ Jl. Siwalankerto 121-131, Surabaya 60236, Indonesia \\ * Penulis korespondensi; E-mail: m24416044@alumni.petra.ac.id; yopi.tanoto@petra.ac.id
}

\begin{abstract}
ABSTRAK
Kemudi sepeda motor merupakan bagian penting yang berfungsi untuk mengendalikan arah kendaraan. Bentuk dari kemudi sangat beragam, mulai dari yang mengedepankan estetika sampai kenyamanan. Untuk kenyamanan tentu berbeda-beda setiap pengendaranya, salah satu faktor yaitu tinggi badan pengendara. untuk menyesuaikan kemudi supaya setiap pengendara dapat mengendarai kendaraan-nya dengan nyaman, maka dirancanglah handlebar yang dapat disesuaikan bentuknya dengan mudah. Perancangan adjustable handlebar ini dimulai dengan mendesain mekanisme-mekanisme perubah sudut dan ketinggian yang bisa dilakukan adjustable handlebar. Perancangan ini menghasilkan mekanisme perubahan sudut dengan rentang $30^{\circ}$ dengan step sebesar $10^{\circ}$ dan rentang ketinggian sebesar $10 \mathrm{~cm}$. Pengaturan dapat dilakukan dengan mudah tanpa harus pergi ke bengkel, dan dapat dilakukan setiap saat. Sehingga adjustable handlebar ini memungkinkan untuk memberi kenyamanan untuk setiap pengendaranya, meski pengendara memiliki postur tubuh yang berbeda-beda.
\end{abstract}

Kata kunci: Handlebar, motorcycle, ergonomic.

\begin{abstract}
Motorcycle handlebar is an important part that functions to control the direction of the vehicle. The shape of the handlebar is very diverse, ranging from promoting aesthetics to comfort. For comfort, of course it differs for each rider, one of the factors is the rider's height. To adjust the handlebar so that each rider can drive his vehicle comfortably, a handlebar is designed that can be adjusted easily. The design of this adjustable handlebar begins with designing mechanisms for changing the angle and height that can be adjusted to the adjustable handlebar. This design produces an angle change mechanism with a range of $30^{\circ}$ with a step of $10^{\circ}$ each and a height range of $10 \mathrm{~cm}$. Arrangements can be made easily without having to go to a repair shop, and can be done at any time. So that this adjustable handlebar makes it possible to provide comfort for each rider, even with different body postures.
\end{abstract}

Keywords: Handlebar, motorcycle, ergonomic.

\section{PENDAHULUAN}

Penggunaan kendaraan bermotor roda dua dalam sepuluh tahun terakhir telah mengalami peningkatan sebanyak dua kali lipat. Jumlah kendaraan bermotor roda dua di Indonesia mencapai 113.030.793 kendaraan pada tahun 2017 [1]. Dengan banyaknya pengguna kendaraan roda dua ini maka untuk tingkat kenyamanan berkendara setiap orang harus dapat tercapai. Setiap orang memiliki postur tubuh yang berbeda-beda, sehingga perlu dilakukan penyesuaian terhadap kendaraan produksi masalnya. Salah satu yang dapat diatur adalah bagian kemudi kendaraan.
Penggunaan kemudi yang sesuai dengan postur pengendara akan sangat membantu kenyamanan berkendara. Meski setiap orang memiliki postur tubuh yang berbeda-beda, namun sudut yang ada pada lengan dan telapak tangan pengendara akan sama untuk mencapai kenyamanan saat berkendara. Survey telah dilakukan di Nigeria dengan 120 orang, dan Taiwan dengan 60 orang sebagai sampel. Didapat data sudut $\theta 2$ sebesar $39,7^{\circ}$ dan $\theta 3$ sebesar $140,2^{\circ}$ untuk orang Taiwan. Orang Nigeria didapatkan sudut $\theta 2$ sebesar $40^{\circ}$ dan $\theta 3$ sebesar $139,3^{\circ}$ [2]. $\theta 2$ merupakan sudut lengan dengan badan pengendara, sedangkan $\theta 3$ merupakan sudut siku tangan. Untuk dapat menemukan berapa sudut yang tepat untuk 
orang Indonesia, maka dapat menggunakan bantuan data ketinggian rata-rata orang di negara tersebut. Rata-rata tinggi orang dewasa Indonesia adalah 163 $\mathrm{cm}$, orang Nigeria adalah $167 \mathrm{~cm}$, dan orang Taiwan adalah $173 \mathrm{~cm}$ [3]. Dengan data ini maka dapat diketahui sudut nyaman orang Indonesia. Sudut yang terpengaruh dari kemudi fleksibel ini adalah $\theta 2$ sebesar $40,2^{\circ}$, dan $\theta 3$ sebesar $138.7^{\circ}$

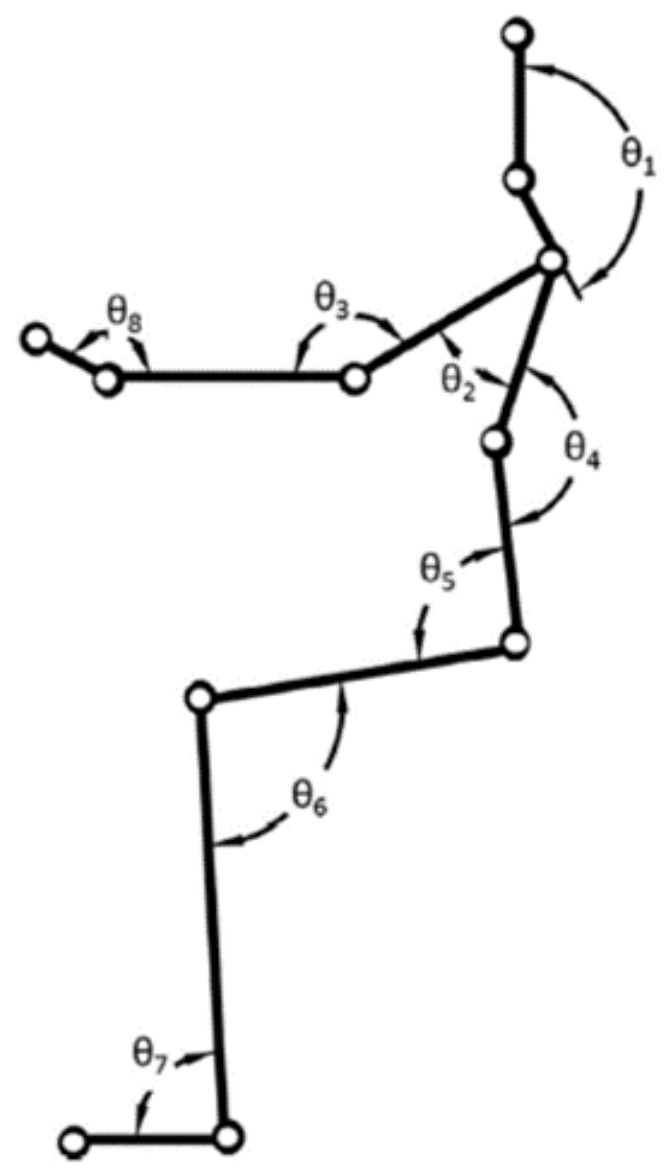

Gambar 1. Sudut kenyamanan pengendara sepeda motor

Dengan melakukan perubahan posisi handlebar, maka sudut lengan dan telapak tangan untuk kenyamanan bisa tercapai. Ini juga memungkinkan posisi pengendara tidak perlu berubah saat berkendara. Jika handlebar ditinggikan maka sudut $\theta 2$ akan semakin membesar dan lebih cocok untuk pengendara yang memiliki postur tubuh yang tinggi. Ini dikarenakan jika pengendara memiliki postur tubuh yang tinggi maka bahu mereka juga lebih tinggi dari kebanyakan orang. Handlebar yang terlalu rendah akan membuat mereka menunduk saat berkendara. Jika perubahan sudut dilakukan dan diatur semakin dekat ke pengendara, maka sudut $\theta 2$, dan $\theta 3$ akan semakin mengecil. Handlebar akan semakin dekat ke pengendara dan akan menimbulkan posisi mengemudi yang baik. Ini lebih cocok untuk pengendara yang memiliki postru tubuh yang pendek. Dengan perubahan yang bisa dilakukan diharapkan mampu mencapai sudut kenyamanan yang telah ditetapkan sebelumnya.
Kendaraan yang telah diproduksi secara masal biasanya kurang dapat diatur atau bisa di atur namun memerlukan keahlian tertentu dan memakan cukup banyak waktu untuk merubah sudut, ketinggian, dan kemiringan kemudinya. Sehingga untuk orang awam akan susah untuk mengubah posisi kemudi yang ada, Dari posisi kemudi yang tetap ini cukup banyak menimbulkan masalah pada orangorang tertentu. Masalah ini cukup berpengaruh pada karakteristik pengendara dalam mengendarai kendaraannya. Jika posisi yang nyaman tercapai dalam pengendara maka akan memberi rasa lebih rileks dan meminimalisir resiko kecelakaan. Data kecelakaan pada perayaan lebaran 2012 mencapai 5.233 kejadian dimana $70 \%$ adalah kendaraan roda dua, dan sebanyak $28 \%$ disebabkan faktor manusia dan penyebab utamanya adalah kelelahan [4].

\section{METODE YANG DIGUNAKAN}

Metode yang digunakan untuk merancang kemudi ini meliputi penentuan parameter yang digunakan untuk menentukan ergonomi pengendara (seperti Sudut siku pengendara, sudut lengan atas pengendara), Perancangan akan difokuskan pada desain kemudi (bentuk engsel pengatur pegangan tangan, sistem pergerakan naik turun kemudi), serta sistem pengunci yang mudah digunakan dan sederhana. Mekanisme ini harus diperhitungkan kekuatannya supaya dapat menerima beban yang terjadi pada kemudi. Dari perhitungan yang telah dibuat maka data tersebut digunakan sebagai acuan untuk memilih material dari komponen yang akan digunakan, dengan mempertimbangkan kekuatan dan estetika-nya. Setelah desain dan material dari kemudi diketahui maka proses selanjutnya adalah pembuatan dan perakitan kemudi fleksibel ini. Perakitan akan dilakukan menggunakan Las SMAW (shilded metal arc welding). Untuk ketebalan las ditetapkan sebesar $3 \mathrm{~mm}$ dengan material yang sama dengan material penyusun kemudi.

Kemudi diuji dengan mencoba mengatur sudut handle di semua range yang ada, mencoba merubah ketinggian kemudi dari yang paling rendah sampai paling tinggi. Jika ada masalah, maka kembali ke bagian merancang desain kemudi dan disempurnakan mekanismenya, jika tidak ada masalah maka dilanjutkan ke proses berikutnya. Menguji penggunaan kemudi dengan posisi kendaraan berjalan, dan dilihat apakah terjadi kendala pada saat kendaraan berjalan pada posisi normal (lurus). Jika tidak ada masalah maka diuji dengan melakukan sedikit manufer. Manufer yang dilakukan adalah membelokkan kendaraan secara penuh kekanan dan kekir. Apakah kemudi mengganggu pengendara untuk berbelok atau tidak. Misalnya mengganggu sistem kelistrikan yang ada atau selang untuk sistem rem atau apakah kemudi ini akan menabrak tangki bahan bakar. Setelah dilakukan semua pengujian 
maka dapat diambil kesimpulan, apakah pengaturan kemudi dapat memenuhi kebutuhan ergonomis pengendara, meski pengendara tersebut postur tubuhnya berbeda-beda. Selain itu juga perlu diperhatikan apakah dengan menggunakan kemudi fleksibel menggangu manufer yang dilakukan saat kendaraan berjalan, dan apakah kemudi ini dapat diubah dengan mudah.

\section{HASIL DAN PEMBAHASAN}

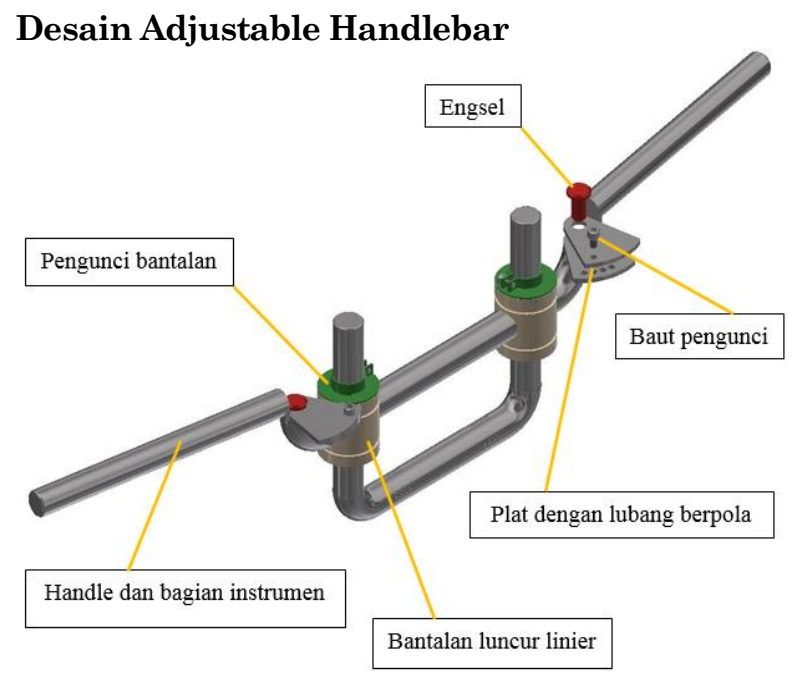

Gambar 2. Desain adjustable handlebar

Dalam merancang produk, maka ada beberapa desain yang harus dibuat guna menentukan desain mana yang palling baik dan mungkin untuk dibuat. Pemilihan desain dilakukan dengan menggunakan metode concept screening. Kriteria yang ada pada concept screening antara lain adalah kemudahan manufaktur, kemudahan pengaturan,estetika, kemudahan perawatan, reliabilitas, durabilitas, dan kemudahan pemasangan. Setelah melakukan metode concept screening maka didapat desain seperti pada Gambar 2, Sehingga kemudi dapat diubah bentuknya dengan ketinggian dan sudut handle yang diinginkan. Untuk sistem perubahan sudut akan menggunakan sistem baut pengunci dengan lubang berpola sesuai dengan sudut yang diinginkan. Sedangkan untuk mekanisme naik dan turun, akan menggunakan sistem sliding dengan clam sebagai pengunci.

Material yang akan digunakan harus memiliki karakter yang baik dan tidak mudah berkarat. Ini dikarenakan posisi kemudi yang akan sangat sering terkena air dan sinar matahari. Material stainless steel dipilih karena memiliki ketangguhan yang baik, dan memiliki ketahanan terhadap karat yang baik. Selain itu, untuk surface finish material ini tidak membutuhkan proses pengecatan atau yang lainnya, hanya membutuhkan pemolesan dan permukaannya sudah terlihat baik. Untuk memperjelas komponen yang digunakan maka dapat melihat parameter awal pada Tabel 1 .
Tabel 1. Parameter desain Adjustable Handlebar

\begin{tabular}{l|c}
\hline \multicolumn{1}{c|}{ Parameter } & Nilai \\
\hline Diameter luar pipa handle & $22,225(7 / 8 \mathrm{inc})(\mathrm{D})$ \\
Diameter dalam pipa handle & $19 \mathrm{~mm}(\mathrm{~d})$ \\
Panjang handle & $240 \mathrm{~mm}(\mathrm{~L})$ \\
Diameter luar pipa U & $25 \mathrm{~mm}$ \\
Ukuran linear bearing & LM25UU \\
Rentang perubahan ketinggian & $100 \mathrm{~mm}$ \\
Rentang perubahan sudut handle & $0^{\circ}, 10^{\circ}, 20^{\circ}, 30^{\circ}$ \\
Material yang digunakan & Stainless steel $304(215 \mathrm{Syp})$ \\
\hline
\end{tabular}

\section{Menghitung Kekuatan Pipa}

Kekuatan pipa dihitung guna mencari berapa gaya yang dapat diterima sebelum pipa tersebut mengalami deformasi plastis. Gaya yang didapat akan digunakan sebagai acuan untuk kekuatan mekanisme lainnya. Sehingga jika terjadi kerusakan maka diharapkan yang rusak terlebih dahulu adalah komponen pipa terlebih dahulu. Ini dikarenakan komponen lain seperti engsel dan clamp pengunci dapat disesuaikan kekuatannya tergantung kebutuhan. Perhitungan dapat dilihat pada Tabel 2,

Tabel 2. Perhitungan kekuatan pipa

\begin{tabular}{c|c|c}
\hline Momen & $M=L \times F$ & $0,24(\mathrm{~F})$ \\
Jari-jari diameter luar & $Y=\frac{D o}{2}$ & $0,0111125 \mathrm{~m}$ \\
Momen area inersia & $I=\frac{\pi}{64} \times\left(D o^{4}-D i^{4}\right)$ & $5,57958 \times 10^{-9} \mathrm{~m}^{4}$ \\
Tegangan bending & $\sigma_{b}=\frac{M \times Y}{I}$ & $477993,1794(\mathrm{~F}) \mathrm{N} / \mathrm{m}^{2}$ \\
Tegangan bending & $\sigma_{b} \leq 0,6 \times S y p$ & $129 \times 10^{6} \mathrm{~N} / \mathrm{m}^{2}$ \\
(allowable) & & $269,88 \mathrm{~N}$ \\
\hline Gaya yang diperlukan & $\sigma_{b} \leq \sigma_{b}$ allowable & 26 \\
\hline
\end{tabular}

Dari perhitungan diatas, didapatkan besar gaya yang dibutuhkan untuk merusak pipa sehingga pipa tersebut tidak dapat kembali ke bentuk semula. Untuk bagian yang dilakukan perhitungan adalah bagian yang memiliki lengan terpanjang yaitu pada bagian pegangan tangan sepanjang $24 \mathrm{~cm}$. Mengapa perhitungan dilakukan pada bagian ini, dikarenakan bagian ini merupakan bagian yang paling lemah atau paling mudah rusak ketika terjadi benturan. Besar angka yang didapat adalah 269,88 Newton.

Setelah mendapat besaran gaya yang diperlukan untuk merusak pipa, maka dilakukan simulasi pada software autodesk inventor profesional 2019. Dari simulasi ini akan didapatkan dimana posisi yang akan pertama kali mengalami kerusakan, dan berapa tegangan atau stress yang akan terjadi pada bagian itu. Simulasi ini dapat dilihat pada gambar 3 .

Metode penyambungan pipa dengan bagian lain adalah menggunakan proses pengelasan SMAW. Ketebalan filler yang digunakan adalah $3 \mathrm{~mm}$ dengan material yang sama seperti material dasarnya. Material yang sama akan membentuk ikatan homogen pada material, sehingga proses pengelasan akan membentuk ikatan yang kuat. Tegangan yang harus ditanggung sambungan las harus dibawah syp material, supaya tidak terjadi kerusakan pada titik pengelasan. 


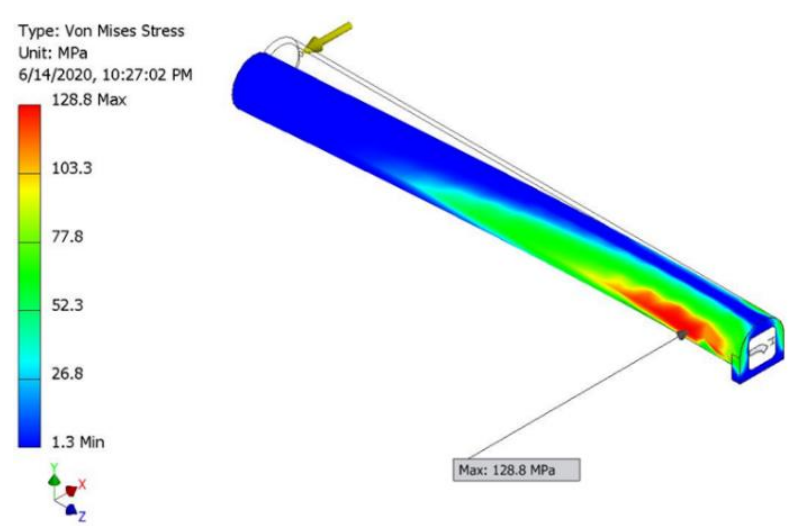

Gambar 3. Analisa tegangan pada pipa

$$
\begin{gathered}
\sigma=\frac{32 \times M}{\pi \times D^{3}\left[1-\left(\frac{D-2 \times a}{D}\right)^{4}\right]} \\
\sigma=\frac{32 \times 64771,2 \mathrm{Nmm}}{\pi \times 22,225^{3} \mathrm{~mm}\left[1-\left(\frac{22,225 \mathrm{~mm}-2 \times 3 \mathrm{~mm}}{22,225 \mathrm{~mm}}\right)^{4}\right]} \\
\boldsymbol{\sigma}=\mathbf{8 3 , 9} \mathbf{M p a}
\end{gathered}
$$

\section{Menghitung Kekuatan Mekanisme Perubah Sudut}

Setelah mendapat gaya kritis, maka kekuatan mekanisme sudut dapat dihitung. Gaya yang bekerja pada pin adalah $1850,59 \mathrm{~N}$, angka ini didapat dari perbandingan jarak pemberian gaya (F) dengan letak pin. Jarak poros dengan pin (x1) lebih pendek jika dibandingkan jarak poros dengan titik pemberian gaya (x2). Sehingga gaya yang diterima oleh pin (F1) lebih besar dibandingkan dengan gaya yang diberikan (F2), dapat dilihat pada gambar 4. Kemudian pada komponen pin perlu diberikan safety factor, besar safety factor yang digunakan adalah 1.5 [5].

$$
\begin{array}{r}
\frac{F \times 4}{\pi \times d^{2}} \leq \frac{0,58 \times S y p}{N} \\
d \geq \sqrt{\frac{1,5 \times 1850,59 N \times 4}{0,58 \times 215 M p a \times \pi}} \geq \mathbf{5 , 3 2 ~ \mathbf { ~ m m }}
\end{array}
$$

Dari perhitungan didapatkan diameter pin yang harus digunakan adalah lebih besar dari 5,32 mm. Dengan menyesuaikan ukuran baut yang ada di toko maka digunakan baut dengan diameter $6 \mathrm{~mm}$, diameter ini dipilih yang lebih besar dari perhitungan supaya mampu menahan gaya yang terjadi.

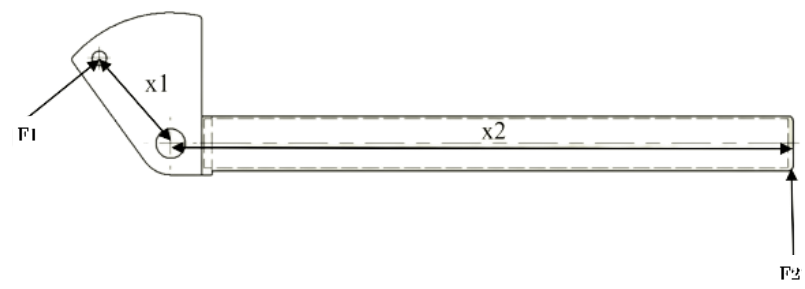

Gambar 4. Free body diagram pada bagian pegangan tangan

\section{Menghitung kekencangan baut pada clamp linear bearing}

Mekanisme gerak naik dan turun kemudi menggunakan sistem sliding dengan linear bearing. Untuk menahan supaya kemudi tidak naik dan turun dengan sendirinya maka diberi pengunci. Pengunci ini berbentuk seperti sabuk pengikat yang dikencangkan menggunakan baut $(\mathrm{Ft})$, free body diagram dapat diliohat pada gambar 5 Gaya yang diberikan sebesar $\mathrm{F}=269,88 \mathrm{~N}$ dengan koefisien gesek statis $\mu s=0,7$, dan safety factor yang digunakan adalah 1,5.

$$
\begin{gathered}
F_{s}=\frac{\mu s \times 2 \times \pi \times F_{T}}{N} \\
F_{T}=\frac{269,88 \mathrm{~N} \times 1,5}{0,7 \times 2 \times \pi}=\mathbf{9 2 , 0 4 ~} \mathbf{N}
\end{gathered}
$$

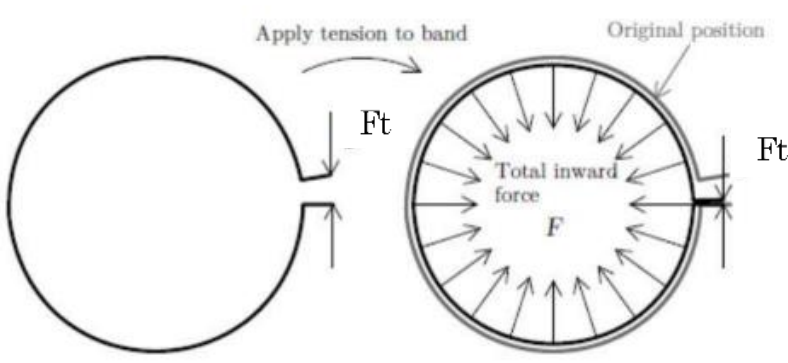

Gambar 5. Free body diagram pada clamp

Tegangan yang dibutuhkan untuk menahan gaya yang diberikan telah diketahui sehingga dapat dilanjutkan untuk mencari torsi atau kekencangan baut yang diperlukan. Diameter baut yang akan digunakan adalah $\mathrm{d}=6 \mathrm{~mm}$, dan koefisien bautnya adalah $\mathrm{K}=0,2$

$$
T=K \times F_{T} \times d
$$

$$
T=0,2 \times 92,04 \mathrm{~N} \times 0,006 \mathrm{~m}=\mathbf{0}, \mathbf{1 1} \mathbf{~ N m}
$$

Sambungan antar clamp dengan linear bearing menggunakan pengelasan dengan panjang $1=10$ $\mathrm{mm}$, dan ketebalan las $3 \mathrm{~mm}$. dan tegangan yang ditanggung oleh sambungan las adalah

$$
\begin{gathered}
\sigma=\frac{P}{h \times l} \\
\sigma=\frac{269,88 \mathrm{~N}}{3 \mathrm{~mm} \times 10 \mathrm{~mm}}=\mathbf{8 , 9 9} \mathbf{M p a}
\end{gathered}
$$

\section{Pengaturan kemudi untuk memenuhi sudut ergonomi}

Pengaturan setiap pengendara berbeda-beda. Beberapa orang mengatur posisi yang sesuai dengan gambar 1 untuk sudut $\theta 2$ dan $\theta 3$. Beberapa orang melakukan pengaturan sedikit berbeda dari yang dianjurkan. Sehingga untuk digunakan berkendara dengan waktu yang lama maka tetap dapat menimbulkan kelelahan pada pengendara. Maka dibuatlah 
anjuran pengaturan untuk ketinggian dan sudut handle pada kemudi, supaya pengendara mendapat pengaturan yang paling baik. Tabel ini dibuat untuk kendaraan Vixion yang mempunyai sudut caster $26^{\circ}$, posisi kemudi dapat dilihat pada Tabel 3.

Tabel 3. Anjuran posisi ketinggian dan sudut Handlebar

\begin{tabular}{ccc}
\hline Tinggi Badan $(\mathrm{cm})$ & Posisi Ketinggian $(\mathrm{cm})$ & Sudut Handle \\
\hline $160-164$ & 0 & $20^{\circ}$ \\
$165-169$ & 3 & $10^{\circ}$ \\
$170-174$ & 6 & $20^{\circ}$ \\
$175-180$ & 10 & $30^{\circ}$ \\
\hline
\end{tabular}

Data pada Tabel 3 akan mempermudah pengendara untuk mendapatkan posisi yang paling tepat berdasarkan sudut erogonomi lengan dan siku. Posisi ketinggian $0 \mathrm{~cm}$ adalah posisi paling bawah, dan ketinggian $10 \mathrm{~cm}$ adalah yang paling tinggi. Untuk posisi sudut handle $0^{\circ}$ adalah sejajar dengan bagian tengah atau lurus, sedangkan posisi $10^{\circ}$ adalah step kedua setelah $0^{\circ}$. Untuk sudut $20^{\circ}$ dan $30^{\circ}$ atau sudut paling besar adalah step ketiga dan step keempat. Posisi ketinggian dan sudut dapat dilihat pada Gambar 6, dan Gambar 7

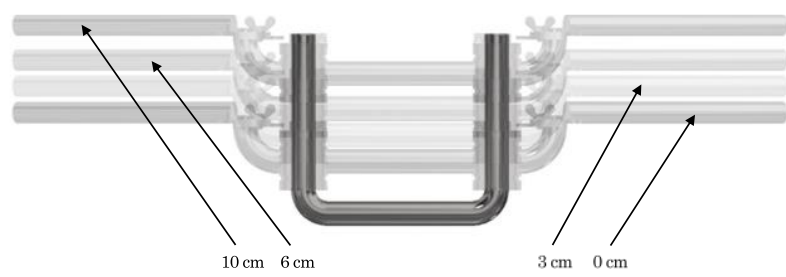

Gambar 6. Macam-macam posisi ketinggian

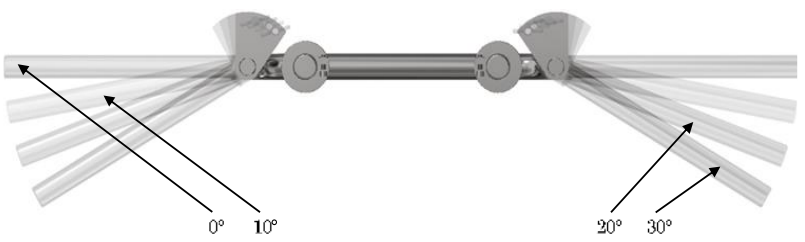

Gambar 7. Macam-macam posisi sudut handlebar

Jika pengendara perlu memperbesar sudut $\theta 2$, dan $\theta 3$ maka posisi kemudi perlu ditinggikan. Saat posisi kemudi ditinggikan maka lengan pengendara juga akan naik saat berkendara sehingga menyebabkan sudut $\theta 2$, dan $\theta 3$ bertambah besar. Untuk memperbesar sudut $\theta 2$, dan $\theta 3$ sebenarnya bisa dilakukan dengan posisi duduk pengendara yang dimundurkan, namun ini akan menambah masalah ergonomi pengendara, sehingga lebih baik melakukan pengeturan pada handlebar. Untuk memperkecil sudut $\theta 2$, dan $\theta 3$ maka sudut dari handle dapat diubah semakin besar, seperti pada gambar 7 . Semakin besar sudut handle maka semakin dekat pula posisi handle dengan pengendara. Ini mengakibatkan sudut $\theta 2$, dan $\theta 3$ menjadi semakin kecil. Sehingga kedua system ini dapat bekerja Bersama untuk mewujudkan berkendara yang nyaman.
Pada kedua sistem pengaturan ini telah mempertimbangkan panjang kabel kelistrikan dan selang fluida rem yang terdapat pada bagian kemudi. Sehingga saat kemudi diatur pada posisi paling atas maka sistem kelistrikan dan selang rem yang ada pada kemudi tidak terganggu meski pada posisi lurus atau berbelok. Demikian juga dengan pengaturan sudut, pada posisi membuka paling lebar dan menutup juga tidak menggangu kabel kelistrikan dan selang rem. Pada posisi sudut yang paling dalam $30^{\circ}$ bagian ujung pegangan tangan juga tidak menyentuh tangki bahan bakar meski kemudi dibelokkan penuh baik kekanan atau kekiri.

\section{KESIMPULAN}

Perancangan adjustable handlebar telah dilakukan dan telah direalisasikan. Desain tersebut juga telah diuji coba mekanismenya dan saat berkendara pada kendaraan. Perancangan alat ini memungkinkan pengendara untuk merubah ketinggian dengan rentang $0 \mathrm{~cm}$ sampai $10 \mathrm{~cm}$ dan perubahan sudut handle antara $0^{\circ}$ sampai $30^{\circ}$ dengan step setiap $10^{\circ}$.

Dengan perubahan yang dapat dilakukan besar sudut $\theta 2$, dan $\theta 3$ dapat disesuaikan meskipun pengendara memiliki postur tubuh yang berbedabeda. Meski pengendara memiliki postur tubuh lebih tinggi atau lebih rendah dari ketinggian rata-rata yang ada, sudut $\theta 2$, dan $\theta 3$ yang dianjurkan sesuai gambar 1 masih dapat dicapai. Sehingga kenyamanan berkendara dapat terwujud.

Berdasarkan percobaan penggunaan pada kendaraan, produk ini mampu memenuhi ekspektasi dari kenyamanan pengguna, meski ada satu pengaturan yang jarang dipakai, yaitu posisi sudut handle $0^{\circ}$. Mekanisme ini juga tidak mengganggu saat kendaraan berbelok maksimal.

Bagian yang perlu perhatian dari produk ini adalah pleumasan bagian linear bearing. Meskipun bagian ini tertutup dengan cover dan seal karet, namun tetap perlu diberi grease. Ini akan memungkinkan linear bearing lebih tahan lama dan dapat bergerak dengan lancar. Apabila tidak dilumasi maka saat melakukan perubahan ketinggian menjadi lebih susah dan mengakibatkan rel linear bearing tergores. Jika bagian rel tidak lagi rata maka pergerakan naik dan turun akan berat

\section{DAFTAR PUSTAKA}

[1]. Badan Pusat Statistik. "Perkembangan Jumlah Kendaraan Bermotor Menurut Jenis, 19492017’. [Online]. Available: https://www.bps.go.id/ linkTableDinamis/view/id/1133. (2019) [Acessed on 3 Ocotber 2019].

[2]. Arunachalam, M., Mondal, C., Singh, G., Karmakar, S., 2018, "Motorcycle Riding Posture: A Review”, Elsevier, 134, pp. 395-396. 
[3]. World Data Info. "Body Size by Country". [Online]. Available: https://www.worlddata.info/ average-bodyheight.php. (2019) [Acessed on 15 October 2020].

[4]. Biro Komunikasi dan Informasi Publik. "Kelelahan Jadi Faktor Utama Penyebab Kecelakaan”. [Online]. Available: http://www.dephub.go.id/ post/read/kelelahan-jadi-faktor-utama-penyebab-kecelakaan-14470. (2012) [Acessed on 2 December 2019].

[5]. Maria, R., 2016, "Sumary of Safety Criteria in Design", Automotive Engineering Research Group, Pekan, Universiti Malaysia Pahang, Malaysia. 